\title{
Analisis Karakteristik Teori Antrian Pada Aplikasi Wireless Fidelity Menggunakan Opnet Modeler 14.5
}

\author{
Eko Fajar Cahyadi', Putra Utama Eka Sakti², Alfin Hikmaturokhman ${ }^{3}$ \\ Program Studi Teknik Telekomunikasi, Sekolah Tinggi Teknologi Telematika Telkom \\ Jl. D.I. Panjaitan No.128, Purwokerto, 53147, Jawa Tengah

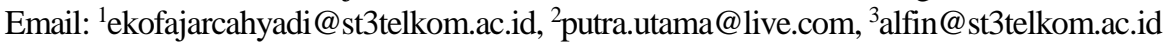 \\ Masuk: 29 April 2015; Direvisi: 13 Juni 2015 dan 29 Juni 2015; Diterima: 4 Juli 2015
}

\begin{abstract}
Wi-Fi areas are accessible in many places, it makes it easier to access the Internet rather than using LAN cable. On the other hand, the Internet itself is a best effort network, which means it does not provide Quality of Service (QoS) mechanism and no traffic classification. This study evaluates the performance of three scheduling methods, including FIFO, Priority Queuing (PQ), and Weighted Fair Queuing (WFQ), on video conference, VoIP and FTP services, implemented in ST3 Telkom campus networks. The results of packet end-to-end delay and packet delay variation for VoIP in WFQ theory scenario is better than the others, that is $171,717 \mathrm{~ms}$ and $0,977 \mathrm{~ms}$. While in video conference services, the result of packet end-to-end delay and packet delay variation in WFQ theory is better than other queuing theory as well, 32,495ms and 7,207ms respectively. This is because the WFQ scheduling mechanism has bandwidth allocation that adapts well to the requirements of the services.
\end{abstract}

Keywords: Wi-Fi, QoS, FIFO, PQ, WFQ

\begin{abstract}
Abstrak. Area Wi-Fi banyak kita jumpai di berbagai tempat, menjadikannya sebagai media akses internet yang lebih mudah untuk digunakan dibandingkan menggunakan kabel LAN. Di lain sisi, internet sendiri merupakan jaringan yang bersifat best effort, yang berarti tidak menyediakan mekanisme Quality of Service (QoS) dan tidak ada klasifikasi trafik layanan. Penelitian ini mengevaluasi mengenai performansi dari tiga metode scheduling, diantaranya FIFO, Priority Queuing (PQ), dan Weighted Fair Queuing (WFQ), pada layanan video conference, VoIP dan FTP, menggunakan topologi Wi-Fi kampus ST3 Telkom. Nilai packet end-to-end delay dan packet delay variation untuk VoIP pada skenario WFQ lebih baik dibandingkan teori antrian lain, yaitu sebesar $171,717 \mathrm{~ms}$ dan $0,977 \mathrm{~ms}$ secara berurutan. Pada video conference, nilai packet end-to-end delay dan packet delay variation WFQ juga lebih baik dibandingkan teori antrian lain, yaitu dengan nilai 32,495ms dan 7,207ms secara berurutan. Hal ini dikarenakan pada WFQ memiliki alokasi bandwidth yang disesuaikan dengan kebutuhan.
\end{abstract}

Kata Kunci: Wi-Fi, QoS, FIFO, PQ, WFQ

\section{Pendahuluan}

Jaringan wireless seperti halnya Wi-Fi (Wireless Fidelity) telah secara luas digunakan di masyarakat karena keunggulan pada biaya yang murah dan penggunaanya yang mudah dalam akses internet. Area jaringan Wi-Fi, atau yang lebih dikenal dengan area hotspot banyak kita jumpai di berbagai tempat, mulai di perumahan, kantor, kafe, dan di lingkungan pendidikan, yang menjadikannya media akses internet yang lebih mudah untuk digunakan dibandingkan menggunakan kabel LAN.

Namun dari semua kelebihan yang dimiliki oleh Wi-Fi sebagai media akses, di lain sisi, internet sendiri merupakan jaringan yang bersifat best effort, yang berarti tidak menyediakan mekanisme Quality of Service (QoS) dan tidak ada klasifikasi trafik layanan, yang merepresentasikan jika ada trafik yang melebihi bandwidth yang telah ditentukan, maka dengan mudah di-drop. Aplikasi real-time seperti video conference, merupakan layanan yang paling 
diprioritaskan untuk mendapatkan jaminan QoS dalam jaringan. Sehingga sangat penting untuk menyediakan jaminan QoS untuk aplikasi yang sensitif terhadap delay dan jitter (Cahyadi, 2014).

Tujuan dari penelitian ini adalah memperlihatkan bagaimana software simulator OPNET dapat digunakan untuk mengevaluasi secara detil kesiapan jaringan IP yang ada dalam mendukung layanan File Transfer Protokol (FTP), video conference, dan Voice over Internet Protocol (VoIP). Yaitu dengan mengevaluasi beberapa metode scheduling yang digunakan untuk mendapatkan nilai kinerja QoS yang cocok untuk digunakan dalam topologi jaringan kampus ST3 Telkom.

OPNET Modeler 14.5 sendiri merupakan software simulator yang digunakan untuk merancang dan mempelajari jaringan komunikasi, perangkat komunikasi, protokol dan aplikasi yang digunakan. OPNET Modeler juga menyediakan antarmuka grafis editor untuk membangun berbagai model jaringan mulai dari lapisan fisik modulator hingga proses aplikasi. OPNET Modeler mendukung spesifikasi model sejumlah alat, yang disebut editor. Editor ini menangani informasi model yang dibutuhkan sehingga mirip dengan struktur sistem jaringan yang sesungguhnya (Irianto, 2014).

\section{Tinjauan Pustaka}

Penelitian ini mengevaluasi mengenai performansi dari tiga metode antrian yang umum digunakan, diantaranya First-In-First-Out (FIFO), Priority Queuing (PQ), dan Weighted Fair Queuing (WFQ) untuk melihat diantara ketiga jenis metode antrian tersebut, metode mana yang memberikan kinerja QoS jaringan yang paling baik. Penggunaan ketiga metode antrian di atas bertujuan untuk melihat perbandingan pengaruh antrian FIFO yang parameter pembedanya hanyalah dari waktu kedatangan paket data, PQ yang mengklasifikasikan jenis trafik berdasarkan prioritas layanan, dan WFQ yang merupakan metode antrian yang paling advanced, sama halnya seperti PQ, mengklasifikasikan jenis trafik berdasarkan prioritas, namun dengan memberikan bobot yang fair terhadap tiap-tiap layanan. Layanan yang disimulasikan pun mewakili dari tiga Diffserv Code Point (DHCP) yang berbeda, yaitu FTP mewakili tipe layanan Best Effort (BE), video conference mewakili Assured Forwarding (AF), dan VoIP mewakili tipe layanan dengan prioritas paling tinggi, Expedited Forwarding (EF). Dari ketiga metode antrian tersebut nantinya dapat dikembangkan menjadi beberapa metode antrian yang lebih spesifik dalam penelitian selanjutnya. Metode FIFO adalah metode standar dalam implementasi jaringan, pengklasifikasian trafiknya hanya berdasarkan kepada paket yang masuk pertama kali (first in) dan paket itulah yang akan diproses lebih dahulu (first out) (Syahrial, 2014).

PQ memiliki empat antrian yang telah dikonfigurasikan, yaitu tinggi, sedang, normal dan antrian prioritas rendah. Masing-masing prioritas antrian ini memiliki kapasitas paket default 20,40,60, dan 80. Jika paket yang datang merupakan paket dengan prioritas tinggi, maka metode PQ akan mengutamakan resource yang ada untuk mengirimkan paket-paket tersebut, dan prioritas antrian lain akan kosong (Balasundaram, dkk., 2014). PQ menjadi dasar dari skema penjadwalan berdasarkan kelas antrian. Mekanisme skema ini adalah setiap paket ditandai dengan suatu prioritas kemudian paket diklasifikasikan oleh sistem, dan dimasukkan pada kelas-kelas prioritas yang berbeda-beda. Dalam masing-masing kelas prioritas tersebut paket-paket kemudian dijadwalkan berdasarkan prioritas. Keuntungan dalam penggunaannya praktis di internet yaitu untuk melindungi routing update packets dengan memberikan prioritas yang lebih tinggi dan antrian khusus pada router (Rumani, dkk., 2012).

Sedangkan WFQ merupakan teknik antrian yang berbasis pada aliran data paket antrian. WFQ mengerjakan dua hal secara bersamaan, yaitu penjadwalan terhadap proses antrian dan pengalokasian bandwidth (Mochamad \& Achmad, 2011). WFQ memberikan alokasi bandwidth secara adil (fair) ke semua trafik di jaringan untuk mengendalikan jitter, latency, dan packet loss. Paket diklasifikasikan dan ditempatkan ke dalam antrian (Vijayakumar, dkk., 2013).

Terdapat tiga layanan yang digunakan dalam analisis ini diantaranya adalah FTP, video conference, dan VoIP. FTP adalah suatu protokol yang berfungsi untuk mengirimkan dan menerima file dalam suatu network yang mempunyai dukungan terhadap TCP/IP. Video 
conference merupakan aplikasi multimedia yang memungkinkan komunikasi data, suara, dan gambar yang bersifat duplex dan real-time dapat diterapkan pada jaringan yang memiliki kecepatan transfer data yang besar karena kapasitas bandwidth-nya yang besar (Nurdiansyah, dkk., 2013). Video conference dapat memudahkan orang untuk berkomunikasi jarak jauh dengan menggunakan komputer dan media internet. Sedangkan VoIP merupakan teknologi yang menjadikan media internet untuk bisa melakukan komunikasi suara jarak jauh secara langsung. Sinyal suara analog, seperti yang dapat didengar ketika berkomunikasi di telepon diubah menjadi data digital dan dikirimkan melalui jaringan berupa paket-paket data secara real-time (Elakna, 2011).

Penelitian ini merupakan pengembangan dari penelitian sebelumnya oleh Irianto (2014) yang menggunakan tiga buah layanan yaitu HTTP, FTP, dan video. Parameter throughput dan delay diuji pada semua aplikasi, sedangkan parameter jitter cuma diujikan pada aplikasi video. Dalam penelitian tersebut tidak terdapat pembahasan tentang manajemen trafik dalam hal ini adalah disiplin antrian. Oleh karena itu dalam penelitian ini menggunakan teori antrian untuk mengamati menejemen trafik pada jaringan Wi-Fi STT Telematika Telkom. Sedangkan layanan yang digunakan juga berbeda dengan penelitian sebelumnya. Pada penelitian ini menggunakan FTP, video conference, dan VoIP. Akan tetapi parameter yang dilakukan pengujian tetap sama dimana throughput dan delay diuji pada semua aplikasi, sedangkan parameter jitter diuji pada aplikasi video conference.

\section{Metodologi Penelitian}

\subsection{Metode Pengumpulan Data}

Sebelum membuat model simulasi, maka perlu mengetahui jaringan yang akan dimodelkan, yaitu jaringan kampus ST3 Telkom. Gambar 1 merupakan topologi jaringan kampus ST3 Telkom yang dibuat menggunakan simulator OPNET Modeler 14.5.

Adapun komponen-komponen yang digunakan dalam simulasi menggunakan simulator OPNET ini diantaranya: (1) Application Configuration satu buah. (2) Profile Configuration satu buah. (3) QoS Configuration satu buah. (4) Ethernet4_slip8_gtwy tiga buah, sebagai router. (5) Ethernet16_switch delapan buah, sebagai switch. (6) ip32_cloud satu buah, sebagai IP Cloud. (7) XDSL_Modem satu buah, sebagai modem. (8) wlan_ethernet_router 18 buah, sebagai access point. (9) ethernet_wkstn enam buah, sebagai user dengan LAN. (10) ppp_server tiga buah, sebagai server layanan. (11) wlan_wkstn 90 buah, sebagai user dengan Wi-Fi. (12) Link 100BaseT untuk setiap node lokal. (13) Link ppp_dsl untuk setiap node server.

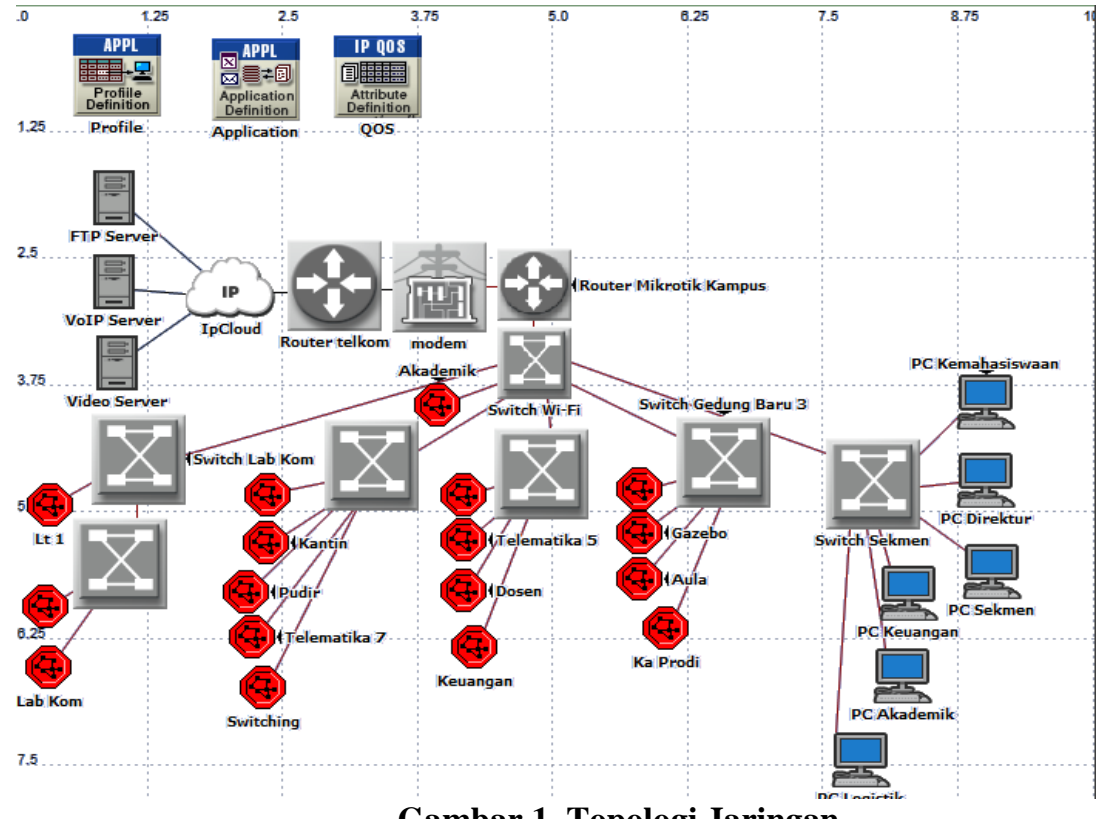

Gambar 1. Topologi Jaringan 


\subsection{Melakukan Simulasi Pada OPNET}

QoS Configuration merupakan konfigurasi dari teori antrian yang digunakan. Teori antrian yang digunakan yaitu FIFO, PQ, dan WFQ. Sedangkan untuk konfigurasi pada $Q o S$ Configuration dilakukan seperti pada Gambar 2.

Skenario yang digunakan pada project ini dibagi kedalam empat skenario yang berbeda (Tabel 1), dimana: (1) Skenario 1 tidak dibandingkan dengan skenario lain. Karena skenario 1 sebagai acuan pertama dalam melakukan simulasi. Dalam skenario ini juga tidak menggunakan disiplin antrian. (2) Skenario 2 dilakukan antrian FIFO dengan parameter yang diamati antara lain delay, jitter, dan throughput. (3) Skenario 3 dilakukan antrian PQ dengan parameter yang diamati antara lain delay, jitter, dan throughput. (4) Skenario 4 dilakukan antrian WFQ dengan parameter yang diamati antara lain delay, jitter, dan throughput.
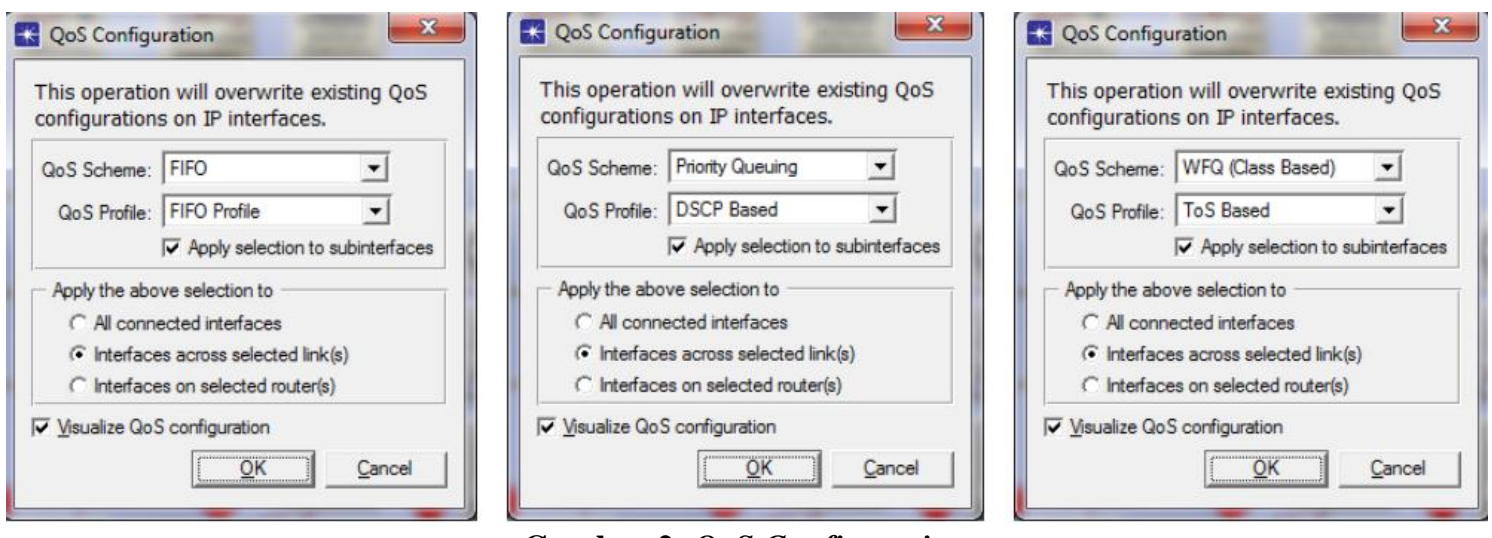

Gambar 2. QoS Configuration

Tabel 1. Skenario yang Digunakan

\begin{tabular}{|c|c|c|c|}
\hline Skenario & Teori Antrian & Layanan & Parameter QoS \\
\hline Skenario 1 & Tanpa Antrian & \multirow{4}{*}{$\begin{array}{c}\text { VoIP, Video } \\
\text { conference, dan } \\
\text { FTP }\end{array}$} & \multirow{4}{*}{$\begin{array}{l}\text { Packet delay end-to-end, Packet delay } \\
\text { variation, dan Throughput, data dropped }\end{array}$} \\
\hline Skenario 2 & FIFO & & \\
\hline Skenario 3 & $\mathrm{PQ}$ & & \\
\hline Skenario 4 & WFQ & & \\
\hline
\end{tabular}

Gambar 3a merujuk pada pengaturan parameter VoIP. Untuk layanan VoIP menggunakan codec G.711 yang merupakan standar internasional untuk audio encoding telepon pada saluran $64 \mathrm{Kbps}$. Ini merupakan skema operasi Pulse Code Modulation (PCM) pada sample rate delapan $\mathrm{kHz}$, dengan delapan bit per sampel. Atribut penting lainnya adalah "voice frame per packet". Voice frame merupakan kumpulan 32 sampel suara yang tiap sampel berukuran 8 bit, yang berarti setiap voice frame berukuran 32 bytes. Sehingga menurut standar yang digunakan, karena paket VoIP mempunyai payload 160 bytes, sehingga kita mengatur nilai pada "voice frame per packet" adalah lima, yang berarti dalam satu paket VoIP terdiri dari lima frame.

Bandwidth yang diperlukan untuk panggilan suara dalam arah apapun adalah sebesar 50 pps (packet per second) atau 90,4 Kbps dengan packet overhead. Codec G.711 menyampel 20 ms suara per paket. Oleh karena itu 50 paket perlu ditransmisikan setiap detiknya, dimana setiap paket terdiri dari 160 sampel suara dalam kaitan untuk menghasilkan 8000 sampel suara per detik. Setiap paket dikirim dalam frame Ethernet. Dengan setiap paket berukuran 160 bytes, ditambah header dari layer protocol (Cahyadi, 2014).

Gambar 3b memperlihatkan konfigurasi aplikasi video conference. Frame interarrival time yang merupakan jumlah frame gambar yang dikirim per detik diatur sebesar 10 frame/sec, dengan frame size information berukuran 128x120 pixel, yang setiap frame setara dengan payload konstan 17280 bytes. Nilai Type of Service (ToS)-nya diubah menjadi AF43 (Assured Forwarding), yang menyatakan nama DSCP-nya, menunjukkan bahwa layanan aplikasi yang didefinisikan video conference merupakan prioritas setelah VoIP. Setelah melakukan setting 
parameter di application configuration dan profile configuration pada semua layanan, kemudian waktu simulasi diatur selama lima menit. Gambar 3c memperlihatkan konfigurasi aplikasi FTP. Sedangkan Tabel 2 menampilkan standarisasi untuk target value performansi delay untuk layanan audio, video, dan data.

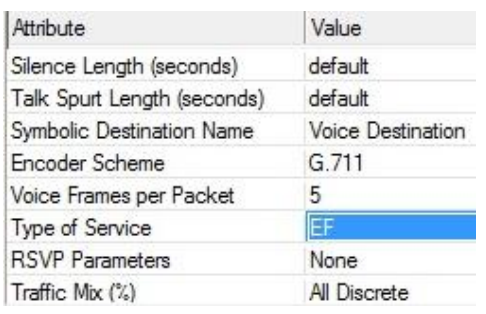

Gambar 3a. VoIP Table

\begin{tabular}{|l|l|}
\hline Attribute & Value \\
\hline Frame Interarival Time Information & 10 frames/sec \\
\hline Frame Size Information (bytes) & $128 \times 120$ pixels \\
\hline Symbolic Destination Name & Video Destination \\
\hline Type of Service & AF 43 \\
\hline RSVP Parameters & None \\
\hline Traffic Mix (\%) & All Discrete \\
\hline \multicolumn{3}{|c}{} \\
Gambar 3b. Video Conferencing \\
Table
\end{tabular}

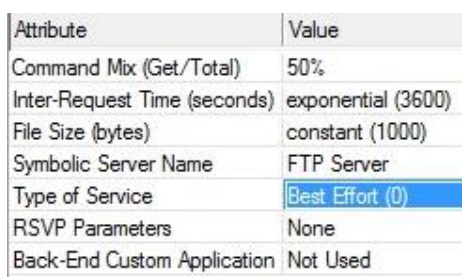

Gambar 3c. FTP Table

Tabel 2. Standarisasi ITU-T G.1010 (ITU-T, 2001)

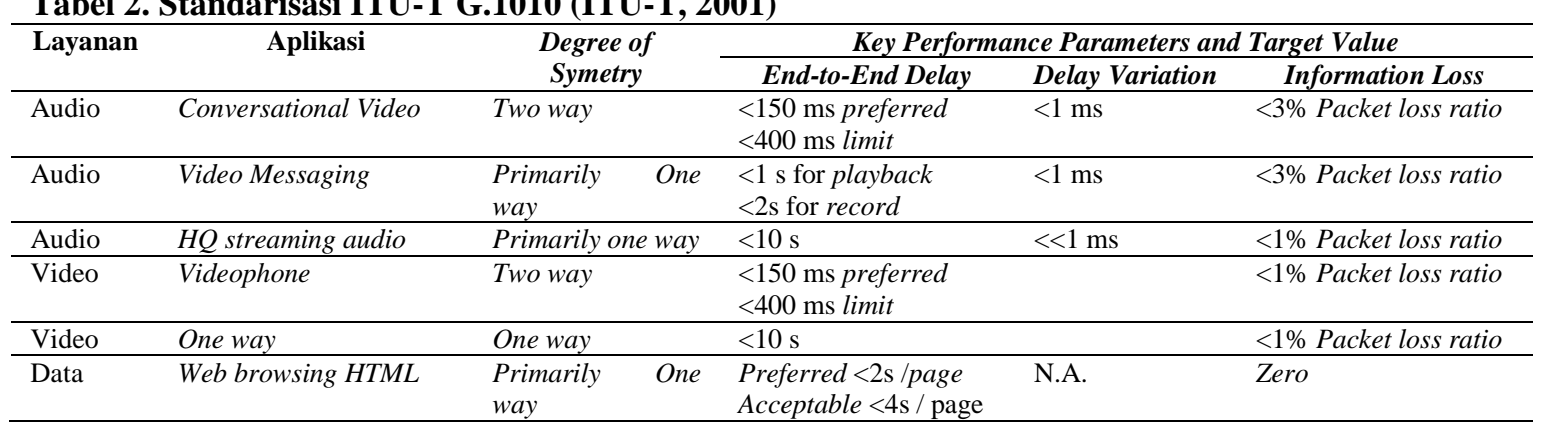

\subsection{Menampilkan Hasil Simulasi}

Pada hasil simulasi, grafik yang ditampilkan memiliki beberapa warna yang membedakan masing-masing skenario yang digunakan. Selain grafik, juga terdapat hasil berupa angka, yang merupakan hasil konversi grafik ke dalam bentuk datasheet. Konversi tersebut bertujuan untuk memudahkan dalam melihat hasil grafik dalam bentuk angka yang lebih detil, sehingga memudahkan pembuatan analisis untuk menentukan teori antrian mana yang terbaik.

\subsection{Menganalisis Hasil Simulasi}

Setelah dilakukan konversi, maka terlihat angka-angka yang muncul untuk selanjutnya dilakukan analisis dengan menggunakan nilai rata-rata sebagai acuan data. Setelah dilakukan analisis terhadap semua parameter yang ada, selanjutnya adalah melakukan analisis data berupa angka-angka. Dari hasil berupa angka tersebut dilakukan pencocokan terhadap standar QoS yang ada dari masing-masing layanan yang digunakan.

\subsection{Membuat Kesimpulan}

Membuat kesimpulan merupakan tahap akhir dalam penelitian. Kesimpulan berisi tentang teori antrian mana yang terbaik dalam topologi yang digunakan dengan layanan FTP, video conference, dan VoIP. Dengan demikian maka dapat diterapkan secara langsung pada dunia nyata agar menghasilkan kualitas yang lebih maksimal. Hasil tersebut juga dibandingkan terhadap standar QoS untuk menentukan yang terbaik.

\section{Hasil dan Pembahasan}

\subsection{Hasil Penelitian}

Pada layanan video conference dilakukan analisis untuk mengetahui teori antrian mana yang terbaik dalam layanan ini. Dalam layanan video conference memiliki dua parameter ukur, yaitu packet end-to-end delay dan packet delay variation. 
Dalam kedua parameter tersebut, semakin besar delay maka kualitasnya semakin buruk. Disiplin antrian FIFO tidak memiliki mekanisme pembagian kelas antrian sehingga pengaturan QoS aplikasi VoIP dan video conference yang bersifat delay sensitive sulit dilakukan. Apabila menginginkan delay yang rendah maka panjang buffer antrian harus dikurangi namun menghasilkan data dropped yang lebih besar. Begitu juga sebaliknya jika menginginkan data dropped kecil maka buffer antrian harus diperpanjang namun berakibat pada delay yang semakin besar. Hal ini berkorelasi pada hasil perbandingan delay dan data dropped yang didapat pada Gambar 4 dan Gambar 5, dimana FIFO memiliki nilai tertinggi, diikuti oleh PQ dan WFQ secara berurutan.

Sama halnya dengan layanan video conference, analisis untuk mengetahui teori antrian mana yang terbaik juga dilakukan pada layanan VoIP. Dalam layanan VoIP memiliki dua parameter yang berbeda, diantaranya packet end-to-end delay dan packet delay variation (Gambar 6 dan Gambar 7 secara berurutan). Semua layanan yang diujikan menggunakan parameter ukur data dropped untuk melihat jumlah data yang tidak dapat ditransmisikan (Gambar 8). Parameter terakhir yang dilakukan simulasi adalah throughput. Grafik hasil throughput dapat dilihat pada Gambar 9.

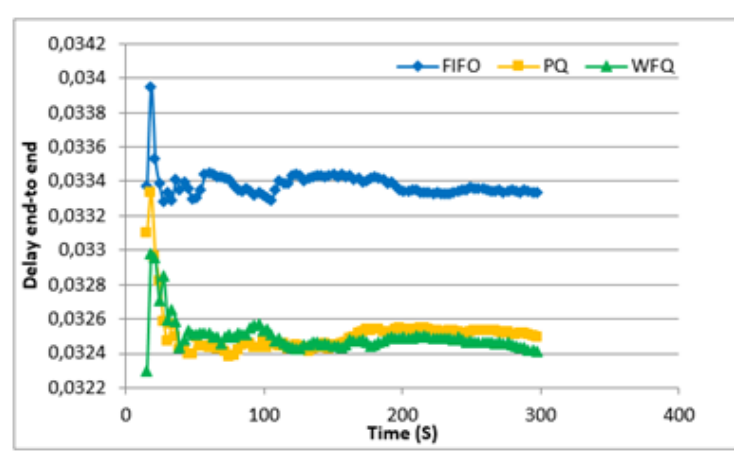

Gambar 4. Packet End-to-End Delay Video Conference

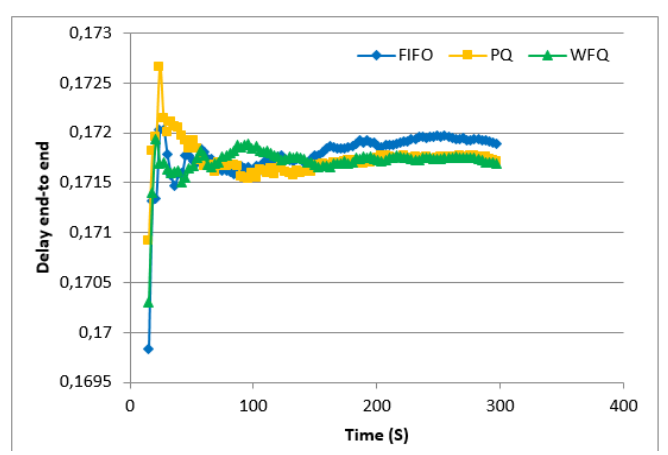

Gambar 6. Packet End-to-End Delay pada VoIP

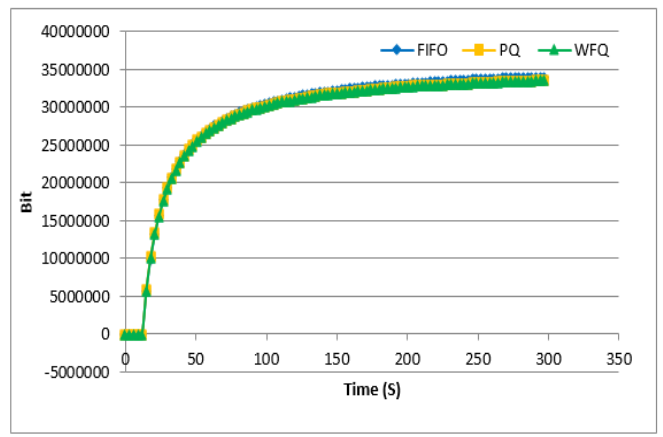

Gambar 8. Data Dropped

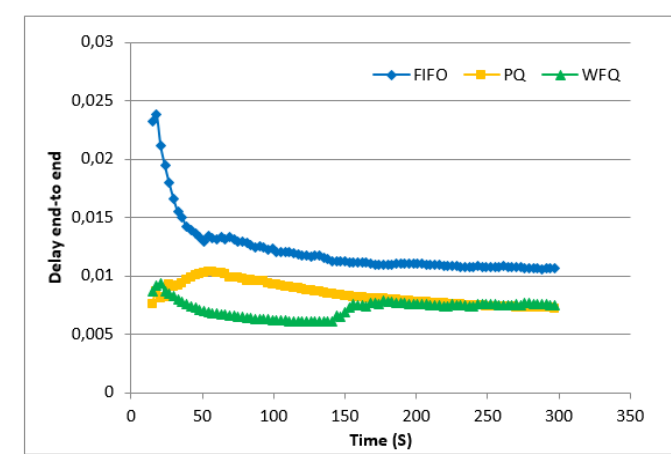

Gambar 5. Packet Delay Variation Video Conference

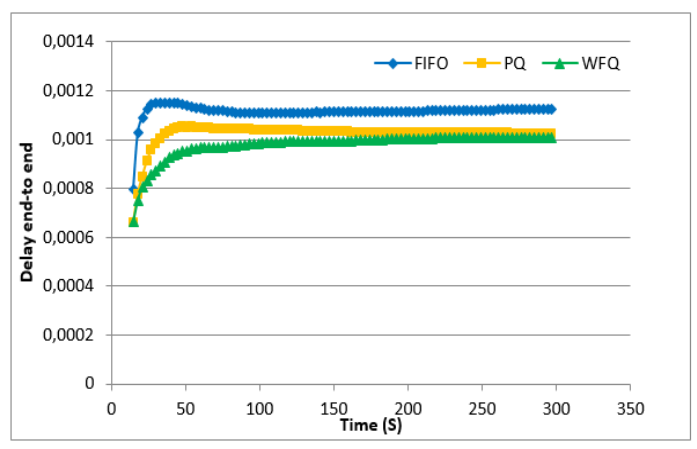

Gambar 7. Packet Delay Variation pada VoIP

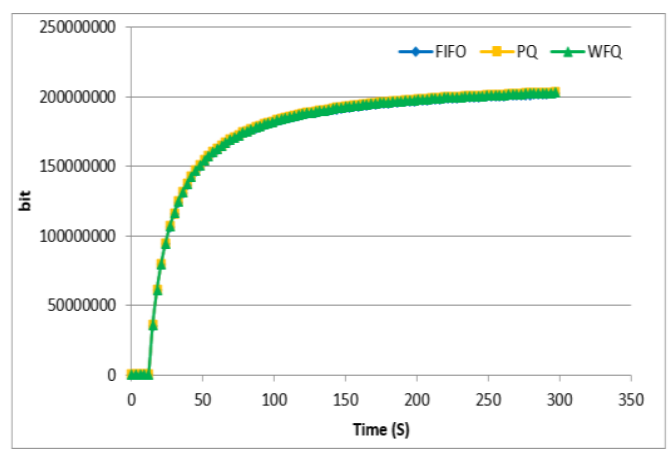

Gambar 9. Throughput 


\subsection{Analisis dan Pembahasan}

Dengan melihat Gambar 4 dan Gambar 5 maka metode antrian FIFO memiliki nilai packet end-to-end delay dan packet delay variation paling tinggi dibandingkan dengan PQ dan WFQ. Selanjutnya untuk PQ memiliki nilai packet delay variation yang lebih rendah dibandingkan dengan FIFO, sedangkan WFQ memiliki nilai yang paling rendah.

Selain dengan grafik, hasil simulasi dapat ditinjau dari nilai rata-rata konversi dari grafik ke datasheet pada Tabel 3. Pada nilai dari teori antrian WFQ pada parameter packet delay end-to-end dan packet delay variation memiliki nilai $32,4959 \mathrm{~ms}$, nilai tersebut sesuai dengan setandar ITU-T G.1010 dengan nilai baik dan 7,20737ms untuk packet delay variation.

Tabel 3. Hasil Rata-Rata Packet Delay End-to-End dan Packet Delay Variation pada Layanan VoIP dan Video Conference

\begin{tabular}{llllll}
\hline Layanan & Parameter & FIFO & PQ & WFQ & Standar \\
\hline Video conference & Packet end-to-end delay & \multirow{2}{*}{$33,3798 \mathrm{~ms}$} & $32,510 \mathrm{~ms}$ & $32,4959 \mathrm{~ms}$ & $<150 \mathrm{~ms}$ preferred \\
& & & & $<400 \mathrm{~ms}$ limit \\
\cline { 2 - 6 } & Packet delay variation & $12,1797 \mathrm{~ms}$ & $8,4206 \mathrm{~ms}$ & $7,20737 \mathrm{~ms}$ & $<1 \mathrm{~ms}$ \\
\hline \multirow{2}{*}{ VoIP } & Packet end-to-end delay & $171,78 \mathrm{~ms}$ & $171,73 \mathrm{~ms}$ & $171,71 \mathrm{~ms}$ & $<150 \mathrm{~ms}$ preferred \\
& & $1,11 \mathrm{~ms}$ & $1,021 \mathrm{~ms}$ & $0,977 \mathrm{~ms}$ & $<1 \mathrm{~ms}$ \\
\cline { 2 - 6 } & Packet delay variation & $2,010293 \mathrm{Mbps}$ & $2,01712 \mathrm{Mbps}$ & $2,01733 \mathrm{Mbps}$ & \\
\hline
\end{tabular}

Pada layanan VoIP terdapat dua parameter yang diukur seperti halnya video conference, diantaranya packet end-to-end delay dan packet delay variation. Dengan melihat Tabel 3 maka packet end-to-end delay dan packet delay variation FIFO memiliki nilai packet end-to-end delay dan packet delay variation paling tinggi dibandingkan dengan PQ dan WFQ. Selanjutnya untuk PQ memiliki nilai packet delay variation yang lebih rendah dibandingkan dengan FIFO, sedangkan WFQ memiliki nilai yang paling rendah.

Dengan demikian maka nilai packet end-to-end delay dan packet delay variation pada WFQ memiliki kualitas yang lebih baik dibanding teori antrian lain. Hal ini dikarenakan pada WFQ memiliki alokasi bandwidth yang disesuaikan dengan kebutuhan. Alokasi bandwidth tersebut disesuaikan dengan layanan yang sensitif terhadap delay. Layanan yang sensitif terhadap delay adalah pertama VoIP, kedua video conference dan terakhir FTP. Dengan demikian maka delay yang dihasilkan semakin kecil, sehingga WFQ lebih efisien dalam jaringan Wi-Fi. Dengan demikian maka data yang di-drop pada WFQ lebih kecil dibanding PQ dan FIFO. Nilai WFQ pada parameter packet delay end-to-end dan packet delay variation memiliki nilai $171,71 \mathrm{~ms}$ dan $0,977 \mathrm{~ms}$. Nilai tersebut sesuai dengan standar ITU-T G.1010 dengan nilai baik.

Parameter data dropped FIFO memiliki nilai tertinggi dibandingkan dengan teori antrian yang lain (Gambar 8). Pada PQ memiliki nilai yang lebih kecil dari FIFO, tetapi perbendaannya sangat kecil. Begitu juga nilai dari WFQ yang memiliki nilai yang terkecil dibandingkan dengan teori antrian yang lain.

Untuk parameter throughput nilai paling tinggi untuk WFQ, sebaliknya nilai terendah adalah nilai untuk FIFO, sedangkan untuk PQ berada di tengah antara WFQ dan FIFO. Hal ini sesuai dengan Gambar 9. Semakin tinggi grafik dalam throughput maka kualitasnya semakin baik. Alokasi bandwidth tersebut disesuaikan dengan layanan yang sensitif terhadap delay, dengan memiliki nilai throughput yang tinggi yaitu 2.017332804 Mbps.

\section{Kesimpulan}

Dari hasil dan pembahasan pada simulasi maka dapat ditarik kesimpulan bahwa pada layanan video conference dan layanan VoIP, baik untuk parameter packet end-to-end delay dan packet delay variation, WFQ lebih baik dibandingkan teori antrian yang lain, dimana untuk layanan video conference pada packet end-to-end delay dengan nilai 32,495 ms dan packet delay variation dengan nilai $7,207 \mathrm{~ms}$. Sedangkan untuk layanan VoIP pada packet end-to-end delay dengan nilai $171,717 \mathrm{~ms}$ dan packet delay variation dengan nilai 0,977 ms. Hal ini 
dikarenakan pada WFQ memiliki alokasi bandwidth yang disesuaikan dengan kebutuhan. Alokasi tersebut disesuaikan dengan layanan yang sensitif terhadap delay.

Pada parameter data dropped, WFQ lebih baik dibandingkan teori antrian yang lain, yang ditandai dengan sedikitnya data yang di-drop yaitu sebesar 0.347623 Mbps. Pada parameter throughput, WFQ lebih baik dibandingkan teori antrian yang lain, yang ditandai dengan banyaknya data yang dikirimkan yaitu sebesar 2.017332804 Mbps. Dengan adanya alokasi bandwidth pada WFQ maka kualitas throughput semakin baik. Alokasi bandwidth tersebut disesuaikan dengan layanan yang sensitif terhadap delay. Dari beberapa parameter yang digunakan, diperoleh hasil WFQ yang paling baik, kemudian disusul oleh PQ, dan terakhir FIFO dalam penerapan teknologi Wi-Fi.

\section{Referensi}

Balasundaram, K., Velmurugan, T., Suresh, R. 2014. Performance Analysis of Queuing Diciplines for Difference Services using OPNET Tool. International Journal of Scientific Engineering and Technology (IJSET), Vol 3, Issue No 1, 1 January 2014.

Cahyadi, E.F. 2014. Assessing Readiness of IP Networks to Support H.323 Desktop Videoconferencing Services over Various Scheduling Techniques Using OPNET. Electrical Power, Electronics, Controls, Communications, and Informatics Seminar (EECCIS) 2014, IEEE Catalog Number: CPF1432Z-CDR, ISBN: 978-1-4799-6946-3.

Elakna. 2011. Analisis dan Perancangan Sistem WLAN. Bandung: Unikom.

Irianto, Dwi Alin. 2014. Perancangan Wi-Fi di STT Telematika Telkom Sesuai Konsep Masterplan Menggunakan Opnet. Purwokerto: STT Telematika Telkom.

ITU-T. 2001. Series G: Transmission Systems And Media, Digital Systems And Networks Quality Of Service And Performance. New York: ITU-Publication.

Mochamad, S., \& Achmad, A. 2011. Perbandingan Priority Queuing (PQ) dan Fair Queuing (FQ) pada 802.11e EDCA untuk Meningkatkan Performansi QoS VoIP over WLAN. Surabaya: ITS.

Nurdiansyah, D.C., Dahlan, E.A., Purnomo, F.E. 2013. Implementasi Video Conference pada Jaringan HSUPA (High Speed Uplink Packet Access) dengan Media IPv6 Menggunakan Simulator Opnet Modeler v14.5. Jurnal Mahasiswa TEUB Vol 1, No. 4, 2013.

Rumani, R. Rudiana, A., Dewantara, A. 2012. Analisa Perbandingan Performansi Skema Scheduling WFQ (Weighted Fair Queuing) dan PQ (Priority Queuing) pada Jaringan IP (Internet Protocol). Jurnal SIFO Mikrosil Vol 13, No. 1, April 2012.

Syahrial, M.R. 2014. Analisa Quality of Service Telephony dengan Metode Low Latency Queuing. IncomTech. Jurnal Telekomunikasi dan Komputer, Vol 5, No. 1, 2014.

Vijayakumar, M., Karthikeyani, V., Omar, M. 2013. Implementation of Queuing Algorithm in Multipath Dynamic Routing Architecture for Effective and Secured Data Transfer in VoIP. International Journal of Engineering Trends and Technology (IJETT), Vol 4, Issue 4 April 2013. 